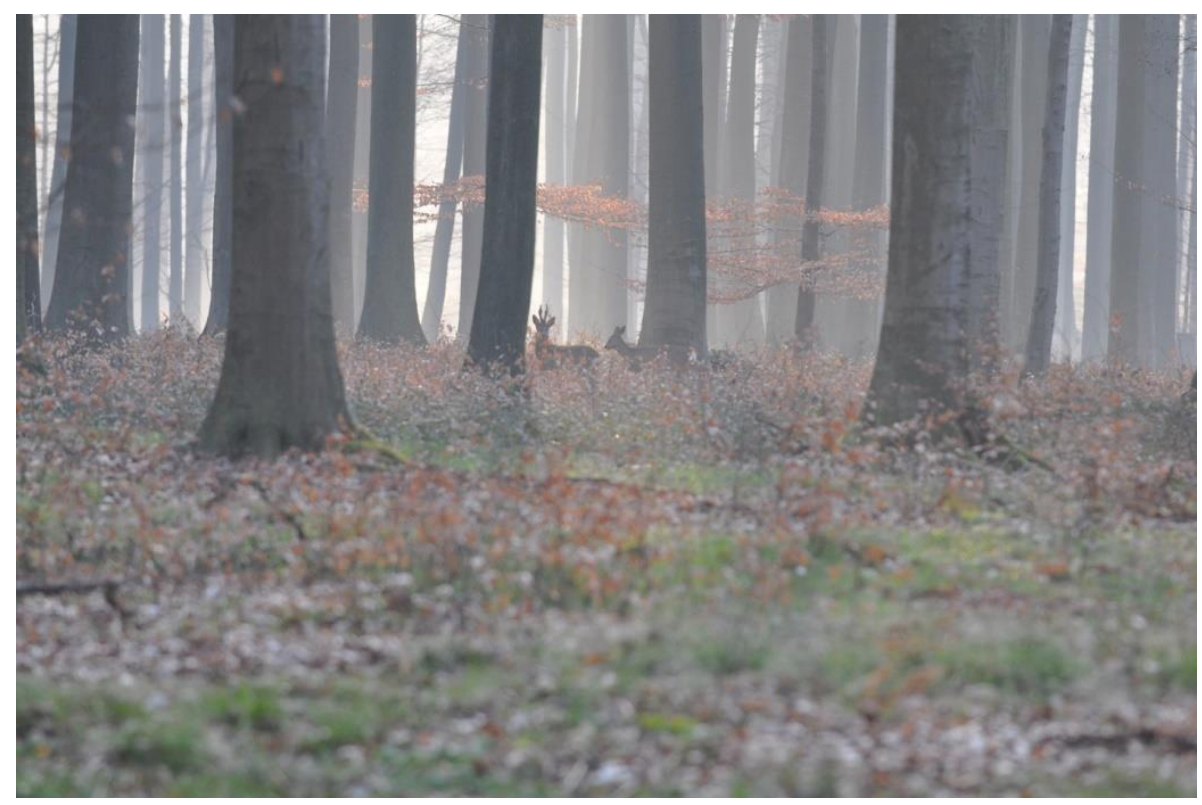

\title{
Ondersteuningsproject bij de uitvoering van de reemonitoring in het Zoniënwoud
}

\author{
Jaarlijks rapport - Referentieperiode: 2008 - 2021 \\ Frank Huysentruyt, Jim Casaer, Jan Vercammen, Niko Boone, Sander \\ Devisscher, Céline Malengreaux, Alain Licoppe
}

September 2021

INSTITUUT NATUUR- EN BOSONDERZOEK
AGENTSCHAP NATUUR \& BOS

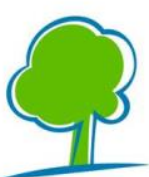

bruxelles environnement leefmilieu brussel brussels a
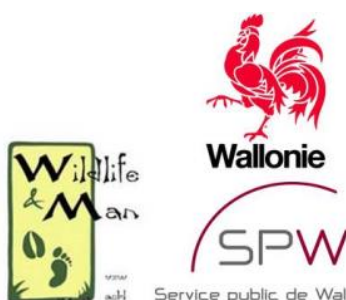

Wallonie

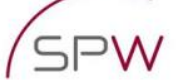




\section{Auteurs:}

Frank Huysentruyt (iD, Jim Casaer (iD), Jan Vercammen, Niko Boone, Sander Devisscher (iD, Céline Malengreaux, Alain Licoppe iD

Reviewers:

Overleggroep grofwild Zoniënwoud

Het INBO is het onafhankelijk onderzoeksinstituut van de Vlaamse overheid dat via toegepast wetenschappelijk onderzoek, data- en kennisontsluiting het biodiversiteitsbeleid en -beheer onderbouwt en evalueert.

\section{Vestiging:}

INBO Brussel

VAC Brussel - Herman Teirlinck, Havenlaan 88 bus 73, 1000 Brussel

https://www.vlaanderen.be/inbo

e-mail:

frank.huysentruyt@inbo.be; alain.licoppe@spw.wallonie.be

\section{Wijze van citeren:}

Huysentruyt et al. (2021). Ondersteuningsproject bij de uitvoering van de reemonitoring in het Zoniënwoud. Jaarlijks rapport - referentieperiode: 2008-2021. Rapporten van het Instituut voor Natuuren Bosonderzoek 2021 (51914322). Instituut voor Natuur- en Bosonderzoek, Brussel. DOI:

doi.org/10.21436/inbor.51914322

\section{D/2021/3241/275}

Rapporten van het Instituut voor Natuur- en Bosonderzoek 2021 (51914322)

ISSN: 1782-9054

Verantwoordelijke uitgever:

Maurice Hoffmann

Foto cover:

Reeën in het Zoniënwoud. Foto door Jan Vercammen.

Dit onderzoek werd uitgevoerd in samenwerking met:

Département de l'Etude du milieu naturel et agricole - DEMNA

Avenue Maréchal Juin 23

5030 Gembloux 


\section{ONDERSTEUNINGSPROJECT BIJ DE UITVOERING VAN DE REEMONITORING IN HET ZONIËNWOUD}

\section{Jaarlijks rapport - referentieperiode: 2008-2021}

Frank Huysentruyt, Jim Casaer, Jan Vercammen, Niko Boone, Sander Devisscher, Céline Malengreaux, Alain Licoppe

doi.org/10.21436/inbor.51914322 


\section{Dankwoord}

Het uitvoeren van de tellingen waarover gerapporteerd wordt in dit rapport, was niet mogelijk zonder de inzet van talloze vrijwilligers afkomstig uit allerlei organisaties en verenigingen. We willen dan ook iedereen bedanken voor de medewerking.

Voor de hulp bij de praktische organisatie bedanken we graag iedereen die hieraan meewerkte bij het Agentschap voor Natuur- en Bos (ANB), Leefmilieu Brussel (BIM), de Service Public de Wallonie (SPW) en het Instituut voor Natuur-en Bosonderzoek (INBO). 


\section{Inhoudsopgave}

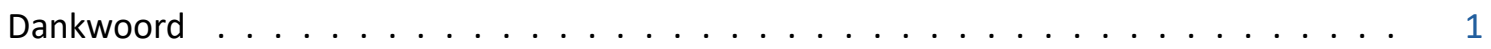

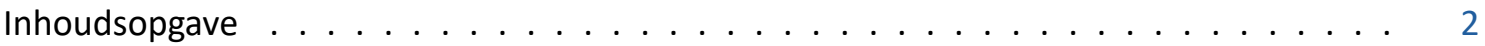

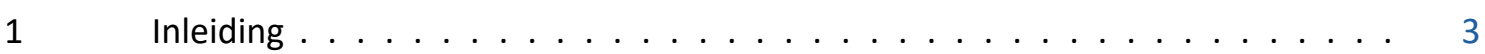

2 De kilometerindex $(\mathrm{KI})$ in het Zoniënwoud . . . . . . . . . . . . . . . 4

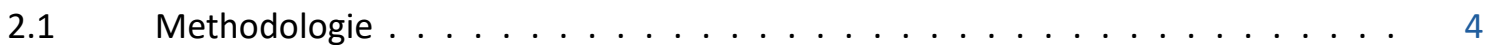

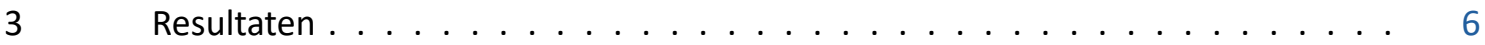

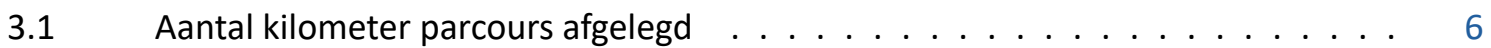

3.2 Maximaal en minimaal aantal waargenomen reeën per jaar . . . . . . . . . 6

3.3 Evolutie van de kilometerindex van 2008 tot $2021 \ldots \ldots$. . . . . . . . . 6

$3.4 \quad$ Evolutie van de kilometerindex per parcours in $2021 \ldots \ldots$

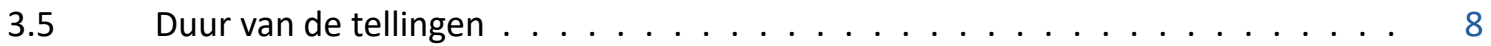

3.6 Oorzaken van veranderingen in het aantal reeën waargenomen per jaar . . . . . 10

3.6.1 Lager aantal reeën . . . . . . . . . . . . . . . . . . . . 10

3.6.2 Verandering van de zichtbaarheid op de trajecten . . . . . . . . . . . . . 10

$4 \quad$ Schatting van de reepopulatie met behulp van distance sampling . . . . . . . . 11

$4.1 \quad$ Methode ......................... 11

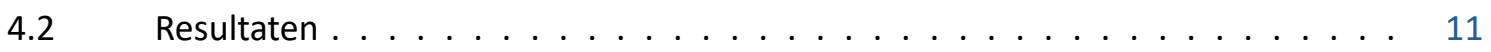

4.2.1 Problemen/knelpunten tijdens het onderzoek . . . . . . . . . . . . . . . 12

$5 \quad$ Conclusies . . . . . . . . . . . . . . . . . . . . . . . 14

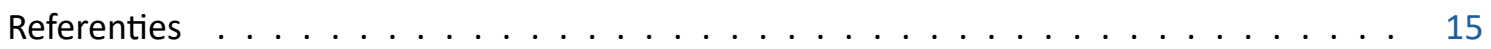




\section{INLEIDING}

Reeën (Capreolus capreolus) zijn een van de grootste zoogdieren in het Zoniënwoud. De soort is in elk deel van het woud aanwezig, maar met wisselende dichtheden.

Om een zicht te krijgen op de evolutie van de reepopulatie in het volledige Zoniënwoud, dus over de drie gewesten heen, voeren het Agentschap voor Natuur- en Bos (ANB), Leefmilieu Brussel (BIM), de Service Public de Wallonie (SPW) en het INBO sinds 2008 jaarlijks systematische tellingen uit in het Zoniënmassief. De vzw Wildlife \& Man stond in voor de voorbereidende studies en bleef daarna betrokken bij de jaarlijkse terugkoppelingsmomenten.

Het is al lang gekend dat het tellen van het aantal aanwezige reeën in een gebied niet mogelijk of moeilijk haalbaar is. Veranderingen of trends binnen een reepopulatie zijn daarentegen wel op te volgen. Wetenschappelijk onderzoek uit Frankrijk toonde aan dat de kilometerindex methode (KI) toelaat om met zekerheid te bepalen of een reepopulatie in een gegeven bosgebied toeneemt, afneemt of stabiel blijft. Deze methode werd in het Zoniënwoud in 2008 opgestart (Vercammen et al., 2011).

Dit rapport omvat een korte beschrijving van de KI-methodologie en geeft de resultaten weer voor de periode 2008-2021. Het rapport is een vervolg op gelijkaardige rapporten uit voorgaande jaren. 


\section{DE KILOMETERINDEX (KI) IN HET ZONIËNWOUD}

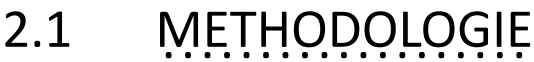

Het principe van de kilometerindex bestaat erin jaarlijks een aantal vaste parcours (figuur 2.1) af te stappen en het aantal waargenomen reeën langs het parcours te tellen. Door vervolgens het aantal reeën te delen door de afgelegde afstand, bekom je een relatieve kilometerindex (het aantal geobserveerde reeën per kilometer). Om uit de index op een statistisch verantwoorde manier conclusies te trekken, zijn jaarlijks minstens 3 à 4 telsessies noodzakelijk. Die worden liefst binnen een zo kort mogelijke periode uitgevoerd. Gedurende elke telsessie worden alle parcours afgestapt. Dat gebeurt bij voorkeur simultaan op dezelfde ochtenden of avonden. Na elke telsessie wordt eerst de kilometerindex per parcours berekend en vervolgens de gemiddelde kilometerindex over alle parcours. Door deze procedure een aantal keer per jaar te herhalen, wordt een jaarlijks gemiddelde bekomen. Op dit gemiddelde kan een betrouwbaarheidsinterval worden berekend. Deze manier van werken laat toe om op een statistisch verantwoorde manier de gemiddelden over een tijdsperiode te vergelijken. Voor meer informatie over deze methode verwijzen we naar Malengreaux \& Casaer (2008). Vroegere resultaten vind je terug in het rapport 'Reewildtellingen' (Vercammen et al., 2011), de daaropvolgende verslagen op de website van het INBO (http://www.inbo.be) en onder de hoofding "Documenten" op de website http://www.wildlifeandman.be. Het meest recente rapport kan je ook telkens in digitale vorm terugvinden op de publicatiepagina van de onderzoeksgroep Faunabeheer en Invasieve soorten van het INBO (https://inbo.github.io/fis-reports/). 


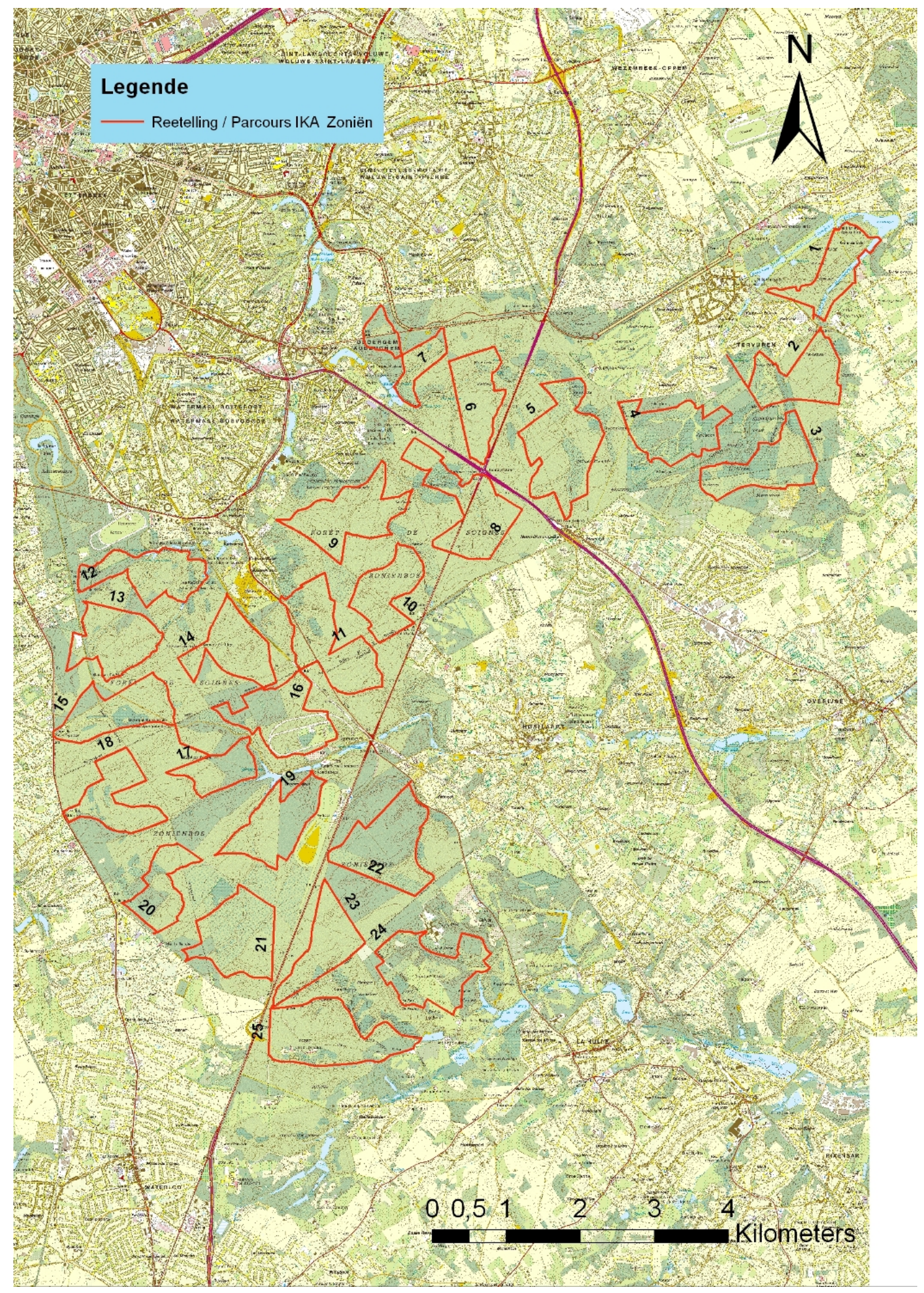

Figuur 2.1: Overzicht van de verschillende telparcours in het Zoniënwoud. Parcours nummer 1 werd enkel in 2008 geteld. 


\section{RESULTATEN}

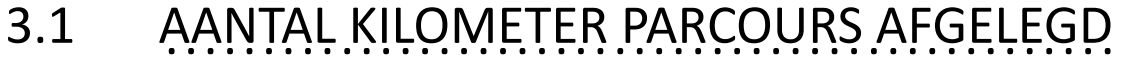

In het verkennend aanvangsjaar 2008 werden er vier ochtend- en vier avondtellingen uitgevoerd. Sinds 2009 vinden de tellingen enkel 's ochtends plaats. De weersomstandigheden bleken immers een zeer grote impact te hebben op het aantal recreanten in de loop van de dag en avond en dus op de mogelijke verstoring voor en gedurende de avondtellingen. Er wordt één keer per week geteld gedurende vier opeenvolgende weken. De 24 telparcours zijn samen $118.4 \mathrm{~km}$ lang. In principe wordt dus jaarlijks $473 \mathrm{~km}$ afgelegd. In 2014, 2016, 2017, 2019, 2020, 2021 werden om uiteenlopende redenen enkele trajecten één of meerdere keren niet geteld. In totaal gaat het om 40 tellingen die niet werden uitgevoerd. Het merendeel daarvan (26) was te wijten aan de coronamaatregelen in 2020. Sinds de start van het project werd in het kader van deze populatie-opvolging al $6900 \mathrm{~km}$ gewandeld.

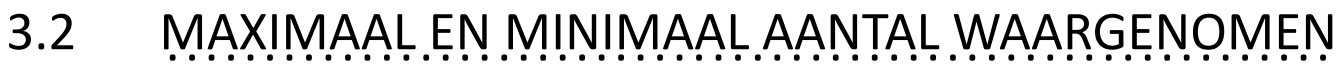

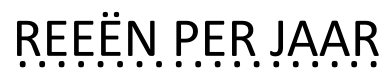

Tabel 3.1 geeft sinds 2012 per jaar de telsessie aan met het hoogste en deze met het laagste aantal waargenomen reeën (voor oudere waarden verwijzen we naar vorige verslagen). De lage aantallen in 2014, 2015, 2016 en 2017 waren mogelijk het gevolg van respectievelijk mist en zware buien op het moment van de betreffende telling. Door het wegvallen van trajecten en/of tellingen geven deze waarden niet altijd een correct beeld van de toestand. Ze geven enkel een indicatie van de grootteorde van de verschillen doorheen de jaren.

Tabel 3.1: Overzicht van het jaarlijks maximaal en minimaal aantal waargenomen reeën tijdens een telsessies voor de laatste 10 monitoringsjaren.

\begin{tabular}{lllllllllll}
\hline jaar & 2012 & 2013 & 2014 & 2015 & 2016 & 2017 & 2018 & 2019 & 2020 & 2021 \\
Hoogst aantal waargenomen reeën & 135 & 153 & 108 & 83 & 93 & 82 & 92 & 88 & 42 & 81 \\
datum maximum & $14 / 03$ & $13 / 03$ & $19 / 03$ & $04 / 03$ & $09 / 03$ & $15 / 03$ & $13 / 03$ & $26 / 03$ & $03 / 03$ & $24 / 03$ \\
Laagst aantal waargenomen reeën & 112 & 85 & 49 & 74 & 36 & 43 & 45 & 56 & 17 & 34 \\
datum minimum & $07 / 03$ & $20 / 03$ & $12 / 03$ & $18 / 03$ & $02 / 03$ & $08 / 03$ & $27 / 03$ & $19 / 03$ & $24 / 03$ & $03 / 03$ \\
\hline
\end{tabular}

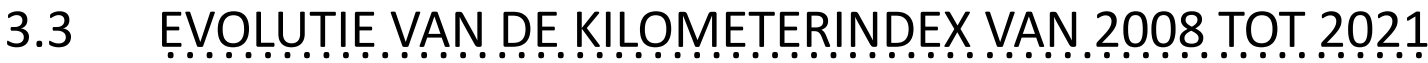

De telresultaten van 2021 bevestigen een dalende tendens. Na het opstartjaar 2008 kunnen we duidelijk twee verschillende perioden onderscheiden (figuur 3.1, 3.2). Een eerste periode, van 2009 tot en met 2013, vertoont een relatief stabiel beeld met een gemiddeld aantal van 1.07 waargenomen reeën per gewandelde kilometer. In de tweede periode lag het jaarlijks gemiddelde tot en met 2019 op 0.62 waargenomen reeën per kilometer. Het leek erop dat er na een periode van afnemende aantallen een nieuwe stabiele toestand was bereikt (geen dalende trend meer), zij het wel op een duidelijk lager niveau dan in de periode tot 2013. 2020 was door de coronamaatregelen een uitzonderlijk jaar en het lage aantal tellingen bemoeilijkt de vergelijking met andere jaren (zie 3.1). Uit de significant lagere waarde (0.34) kunnen we dus geen conclusies trekken. In 2021, waarin opnieuw zo goed als volledig werd geteld, was de gemiddelde waarde 


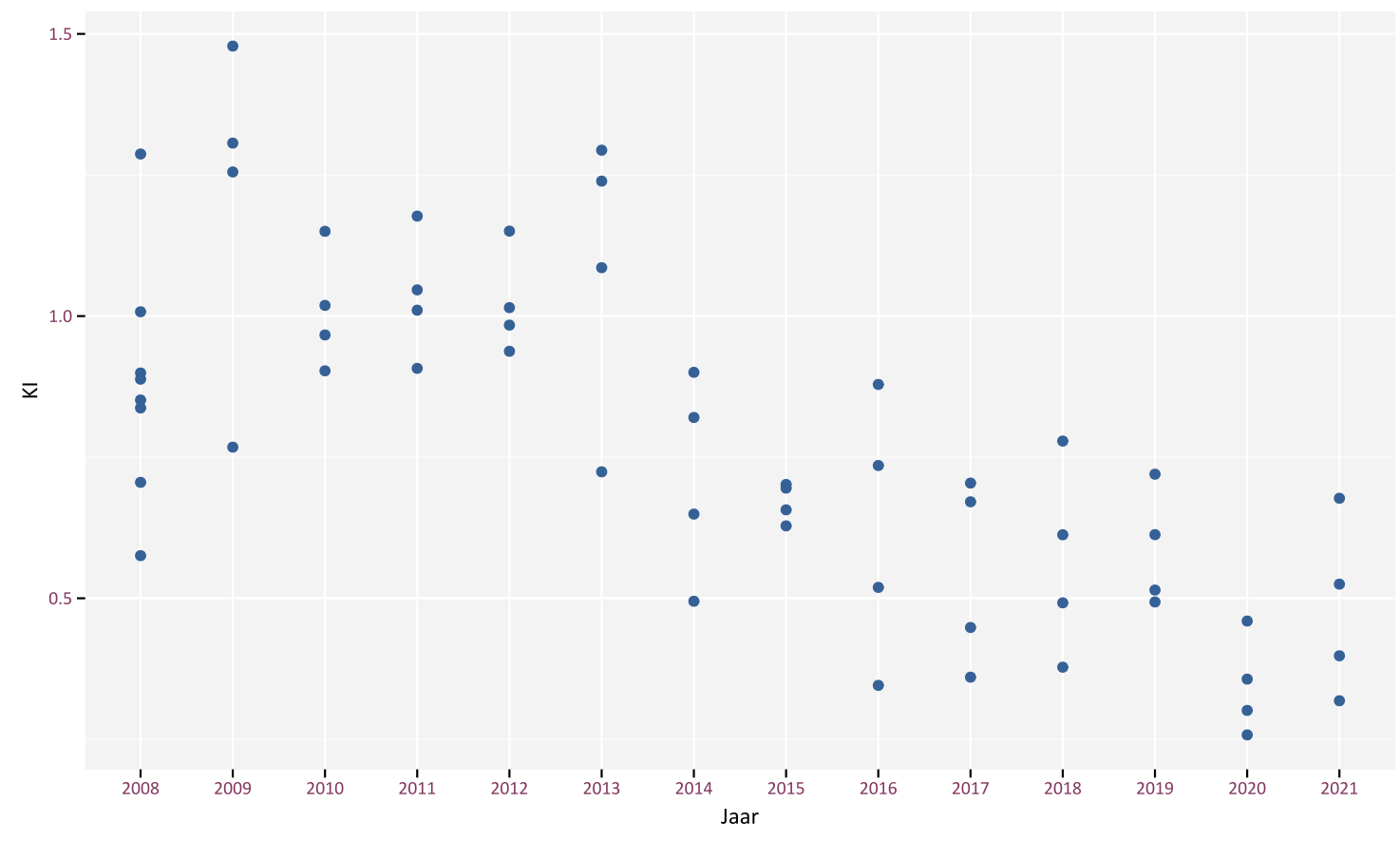

Figuur 3.1: Kilometerindex per telsessie voor de periode 2008-2021 (in 2008 vonden 8 telsessies plaats, vanaf 2009 werden per jaar 4 telsessies georganiseerd).

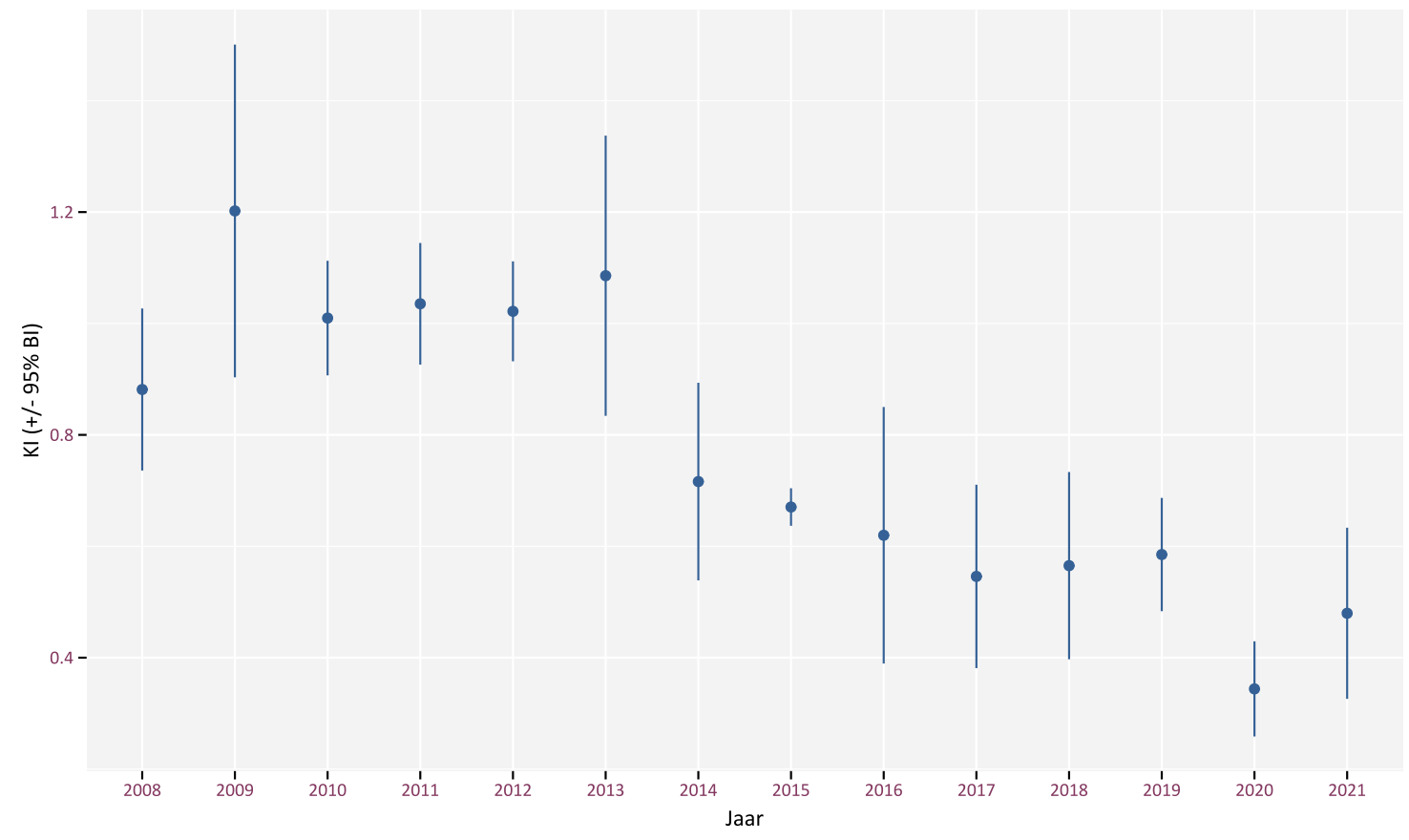

Figuur 3.2: Overzicht van de gemiddelde kilometerindex per jaar voor de periode 2008-2021. 
(0.48) laag in vergelijking met de periode 2014-2019. Dit is een indicatie dat de aantallen toch verder zijn afgenomen.

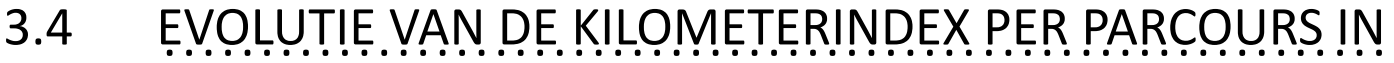 2021}

Wanneer we per parcours de tellingen van 2021 vergelijken met de mediaan jaren ervoor (2008 - 2020), dan zien we drie fenomenen (figuur 3.3):

1. bij 7 trajecten is de $\mathrm{KI}$ bij alle tellingen van dit jaar lager dan de mediaan van de vorige jaren (parcours $2,4,8,9,17,24,25)$

2. bij 18 trajecten zijn op een of meer teldagen geen reeën waargenomen

3. bij 14 trajecten waren er dagen waarop het aantal waargenomen reeën boven de mediaan van de vorige jaren lag.

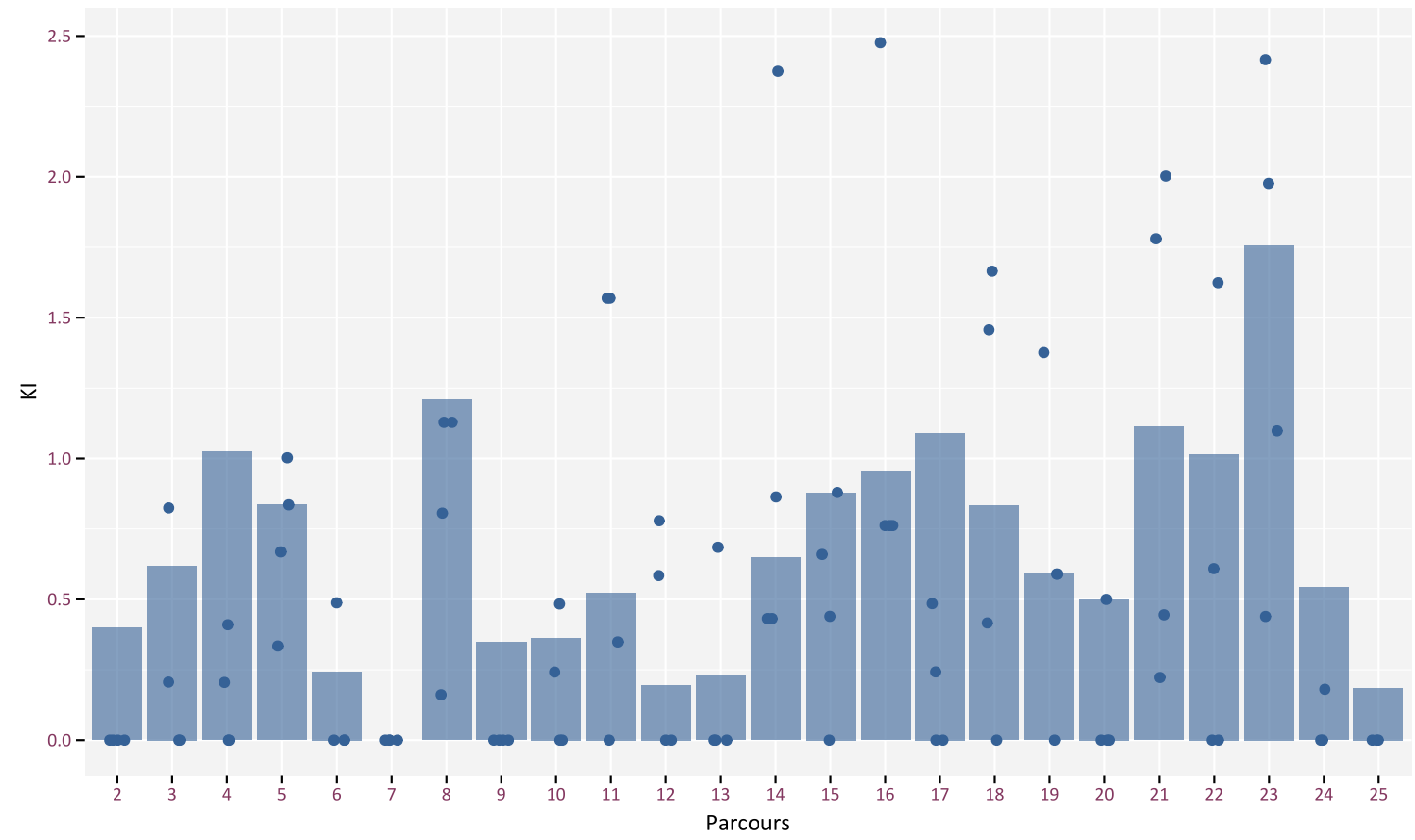

Figuur 3.3: KI per parcours voor de vier verschillende tellingen in 2021 (blauwe bollen) ten opzichte van de mediaan van alle voorgaande jaren (blauwe balk). Parcours 24 werd één keer niet geteld, parcours 25 twee keer.

Wanneer we per parcours de gemiddelde KI voor 2021 vergelijken met de mediaan uit de periode van 2008 tot en met 2013, dus voor de opmerkelijke terugval, dan zien we dat de daling van de KI zich in bijna alle trajecten heeft voorgedaan (figuur 3.4). Enkel in 3 van de 24 trajecten oversteeg het gemiddelde in 2021 de mediaan voor de periode 2008-2013. Bij 14 trajecten ligt het volledige betrouwbaarheidsinterval van de $\mathrm{KI}$ van 2021 onder de mediaan voor de periode 2008-2013. Dat wijst voor deze trajecten op een significante daling sinds 2013.

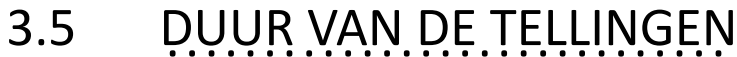

De ideale duur voor het uitvoeren van een telling is 1.30 uur tot 1.45 uur. Met uitzondering van 2011 voldeed de gemiddelde duur hier aan (tabel 3.2). In 2021 was de kortste tijd waarbinnen een telling werd uitgevoerd 1 u en 7 minuten, de langste 2 u en 4 minuten. Dit jaar werden, op een totaal van 92 trajecten 


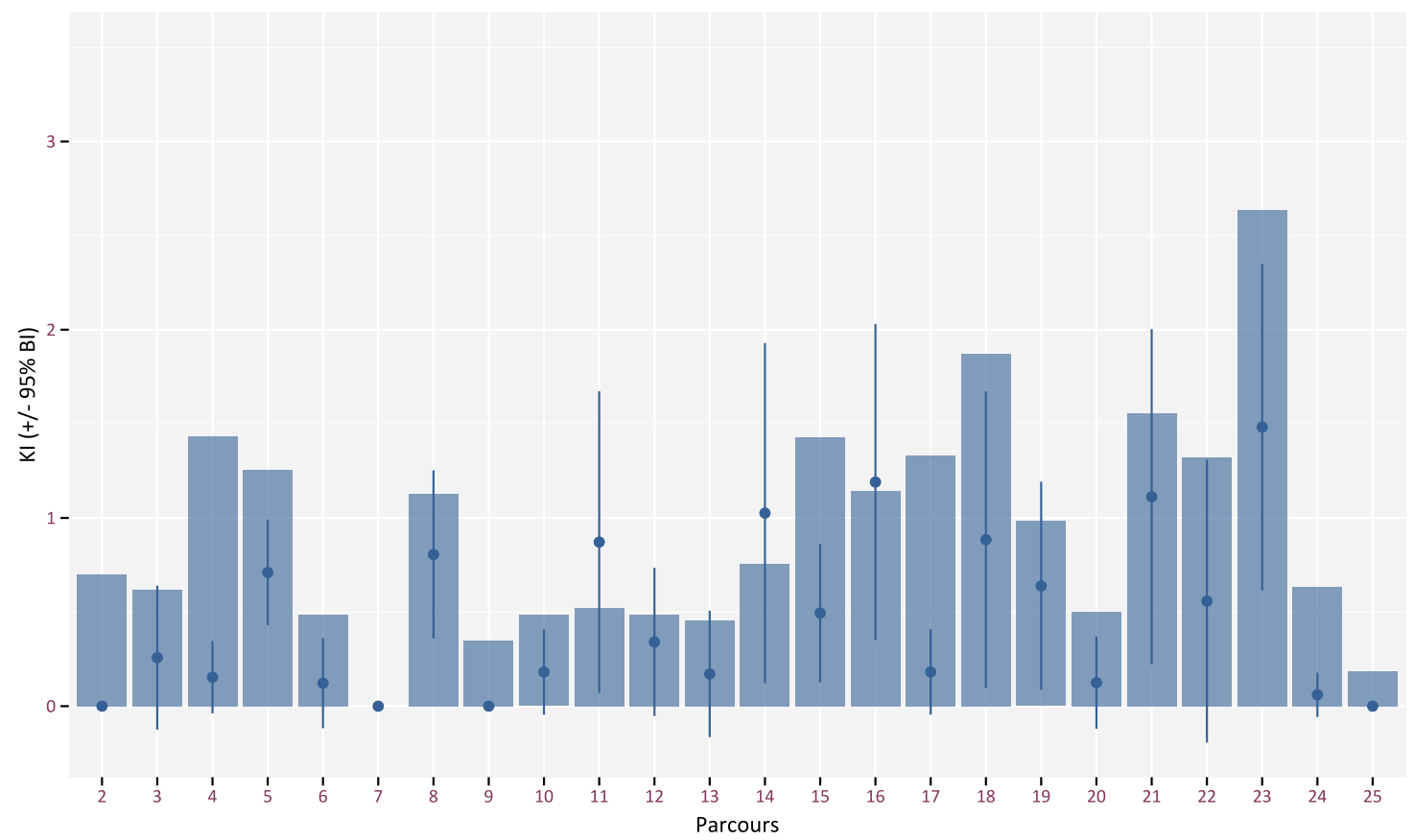

Figuur 3.4: Gemiddelde KI per parcours voor de tellingen in 2021 ten opzichte van de mediaan (blauwe balk) voor de periode 2008-2013, de periode voor de opmerkelijke terugval.

waarvoor de duur van uitvoering gekend was, 29 te snel afgelegd en 23 iets te traag. Dat betekent dat $57 \%$ van alle tellingen niet binnen de ideale tijdspanne werden uitgevoerd. Zeker voor wat de tellingen die te snel werden uitgevoerd, blijft dit een aandachtspunt. Daar bestaat het risico dat aanwezige reeën niet worden waargenomen.

Tabel 3.2: Gemiddelde duur van een telling per teljaar.

\begin{tabular}{r|l}
\hline Jaar & Gemiddelde duur $(u)$ \\
\hline 2008 & $01: 39$ \\
\hline 2009 & $01: 30$ \\
\hline 2010 & $01: 30$ \\
\hline 2011 & $01: 27$ \\
\hline 2012 & $01: 30$ \\
\hline 2013 & $01: 30$ \\
\hline 2014 & $01: 32$ \\
\hline 2015 & $01: 33$ \\
\hline 2016 & $01: 35$ \\
\hline 2017 & $01: 32$ \\
\hline 2018 & $01: 35$ \\
\hline 2019 & $01: 33$ \\
\hline 2020 & $01: 35$ \\
\hline 2021 & $01: 35$ \\
\hline
\end{tabular}




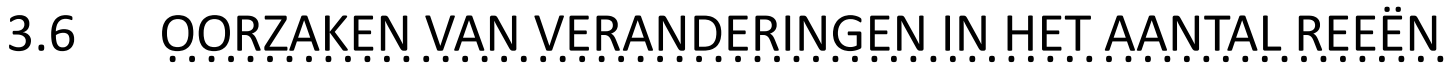 WAARGENOMEN PER JAAR}

De lagere aantallen waargenomen reeën kunnen zowel het gevolg zijn van een effectief lager aantal reeën als van een verminderde waarnemingskans. Onder waarnemingskans verstaan we de waarschijnlijkheid dat een aanwezige ree ook effectief waargenomen wordt. Een verminderde waarnemingskans kan zowel aan een verandering in het gedrag van de reeën te wijten zijn, als aan een verminderde zichtbaarheid door de aanwezigheid van meer dekking (struiken en jonge bomen). In 2020 kan de waarnemingskans ook aan het wegvallen van een groot aantal tellingen gelinkt zijn. Als de waarnemingskans op de dagen waarop wel werd geteld door omstandigheden lager lag (weersomstandigheden, recreatiedruk ...) dan kan dat een effect hebben. Daarom was het wachten op de gegevens van 2021 om conclusies te trekken over de meest recente daling.

\subsubsection{Lager aantal reeën}

Bij een ongewijzigde waarnemingskans betekent een lager aantal waargenomen reeën per kilometer dat het aantal reeën in het Zoniënwoud effectief afneemt. Mogelijke oorzaken daarvan zijn lagere voortplanting, hogere sterfte en/of emigratie. Omdat in het Zoniënwoud geen jacht plaatsvindt, zou een hogere mortaliteit veroorzaakt kunnen worden door een toename van ziektes, predatie, verkeersslachtoffers of loslopende honden. We beschikken echter niet over gegevens van aantallen dood gevonden dieren of over de populatiegegevens van mogelijke predatoren in en rond het Zoniënwoud. Er wordt ook niet systematisch onderzoek naar gedaan. We beschikken ook niet over de nodige gegevens om de hypotheses van lagere geboortecijfers (aantal embryo's per drachtige geit en het aandeel drachtige geiten) of plotse sterke emigratie te kunnen onderzoeken. Ook de vraag of een mogelijke wijziging in recreatiedruk een effect heeft, blijft momenteel onbeantwoord. Een verhoogde recreatiedruk kan resulteren in een emigratie naar rustigere stukken in of buiten het bos, of in een verandering in het gedrag van de reeën. Een eerste stap om dit te onderzoeken is de evolutie nagaan van het aantal recreanten dat jaarlijks het Zoniënwoud bezoekt en/of van de dichtheid van het netwerk aan paden in het boscomplex. Binnen het kader van dit project is deze opvolging echter niet voorzien.

\subsubsection{Verandering van de zichtbaarheid op de trajecten}

Bij een bos dat niet onderhevig is aan sterke veranderingen in beheer of andere externe factoren, wordt in theorie de vermindering in zichtbaarheid op sommige trajecten gecompenseerd door een toename op andere trajecten. Dit is zeker het geval in een groot gebied zoals het Zoniënwoud waar de parcours homogeen over het volledige gebied verdeeld werden. Omdat er in de telperiode 2008-2015 geen metingen uitgevoerd zijn om eventuele veranderingen in de zichtbaarheid aan te tonen, is het niet mogelijk het potentiële effect ervan in te schatten. Om toch te proberen hier een idee over te krijgen, voerden we in 2015 een bevraging uit bij alle tellers. Het resultaat daarvan is besproken in het opvolgingsrapport 2015 (Huysentruyt et al., 2015). Om het effect van veranderingen in zichtbaarheid te kunnen modelleren en op te volgen naar de toekomst toe, werd besloten de zichtbaarheid op de verschillende trajecten effectief te meten (zie hiervoor (Boone et al., 2020)). Een bijkomende mogelijkheid om de verandering in zichtbaarheid na te gaan is de resultaten van zichtbaarheidsmetingen op trajecten te vergelijken met tellingen waarbij ook de afstand tot de waarneming werd gemeten (distance sampling, zie 4). 


\section{SCHATTING VAN DE REEPOPULATIE MET BEHULP VAN DISTANCE SAMPLING}

Het uitgangspunt bij distance sampling is dat de waarschijnlijkheid om een dier waar te nemen daalt in functie van de afstand tussen de waarnemer en het dier (Buckland et al., 2001). De methode bestaat erin de loodrechte afstand te bereken tussen het waargenomen dier en het telparcours. Dit wordt gedaan door de afstand tussen de waarnemer en dier te meten (met een afstandsmeter) zowel als de hoek van deze lijn t.o.v. het telparcours (zie Casaer \& Malengreaux (2008)). Op basis van deze gegevens kan de waarnemingskans in functie van de afstand gemodelleerd worden; een functie die eigen is aan de diersoort en een bepaald gebied/vegetatie (figuur 4.1). Deze functie kan op zijn beurt gehanteerd worden om voor een bepaald gebied de densiteit van dieren te berekenen.

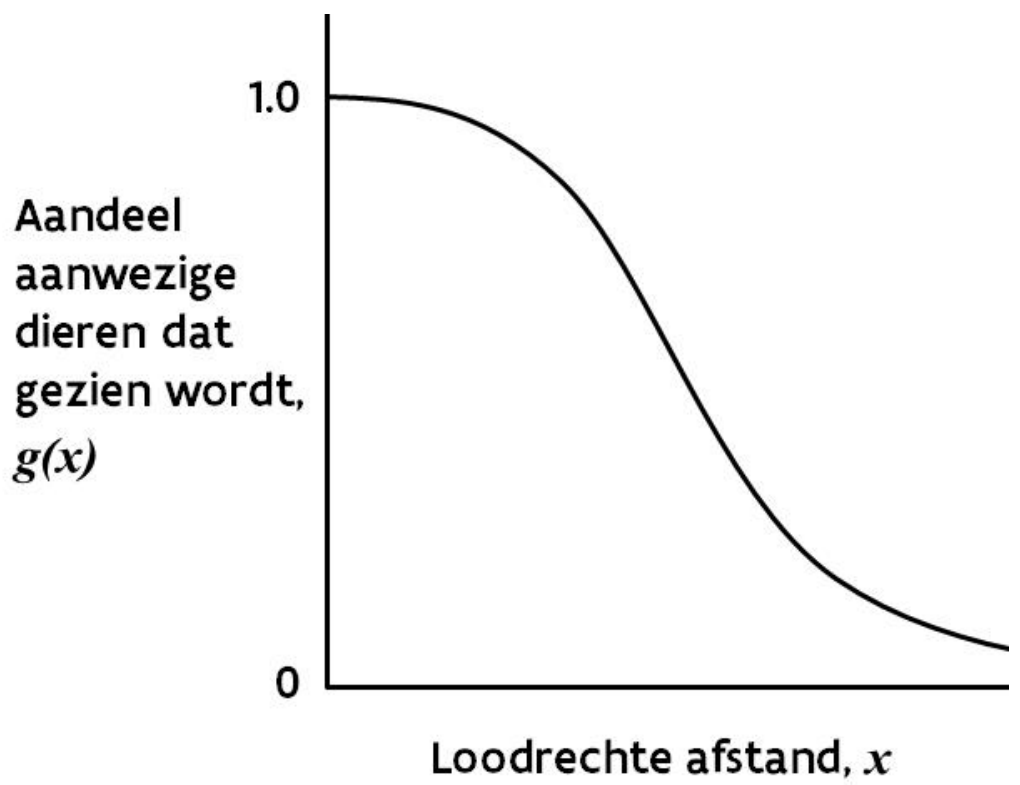

Figuur 4.1: Theoretische functie voor het waarnemen van dieren. Hoe groter de (loodrechte) afstand tussen dier en traject, hoe kleiner de kans op het waarnemen ervan.

\subsection{M!̣THQT!̣E}

Sinds maart 2018 kreeg een deel van de tellers een afstandsmeter ter beschikking. We beschikten echter over onvoldoende toestellen voor alle 24 tellers. Het gebruik van een betrouwbare afstandsmeter is een voorwaarde om distance sampling toe te passen. In tegenstelling tot de normale aanpak werkten we, omdat de hoek niet nauwkeurig kon worden bepaald, met de directe afstand tussen de waarnemer en het geobserveerde dier en niet met de loodrechte afstand.

\subsection{RESTỤTTTATEN}

In totaal werd tussen 2018 en 2021 bij 208 waarnemingen de afstand gemeten. Daarvan werd voor 7 waarnemingen een afstand van 200 m of meer genoteerd, een afstand die buiten de scope van deze 
Distance Sampling valt. Voor de overige metingen blijkt uit Tabel 4.1 dat de gemiddeld gemeten afstand tot een waargenomen dier weinig verschilt tussen de jaren. De gemiddelde afstand van alle 201 waarnemingen met afstandsmeting bedraagt $70.7 \pm 35.8 \mathrm{~m}$. Dit gemiddelde blijkt bovendien vrij robuust en weinig afhankelijk van het aantal uitgevoerde metingen. Wanneer we voor 2021 de gemiddelde waarden per gemeten parcours vergelijken, valt wel op dat de gemiddelde zichtbaarheid tussen trajecten sterk kan verschillen (Figuur 4.2).

Tabel 4.1: Overzicht per jaar van de gemiddelde gemeten afstand $(<200 \mathrm{~m})$ tussen waarnemer en het waargenomen dier.

\begin{tabular}{rrrrr}
\hline Jaar & Aantal trajecten & Aantal waarnemingen & Gemiddelde afstand & Standaarddeviatie afstand \\
\hline 2018 & 17 & 71 & 65.3 & 32.3 \\
2019 & 8 & 38 & 79.5 & 33.8 \\
2020 & 9 & 24 & 72.7 & 34.8 \\
2021 & 12 & 68 & 70.7 & 40.0 \\
\hline
\end{tabular}

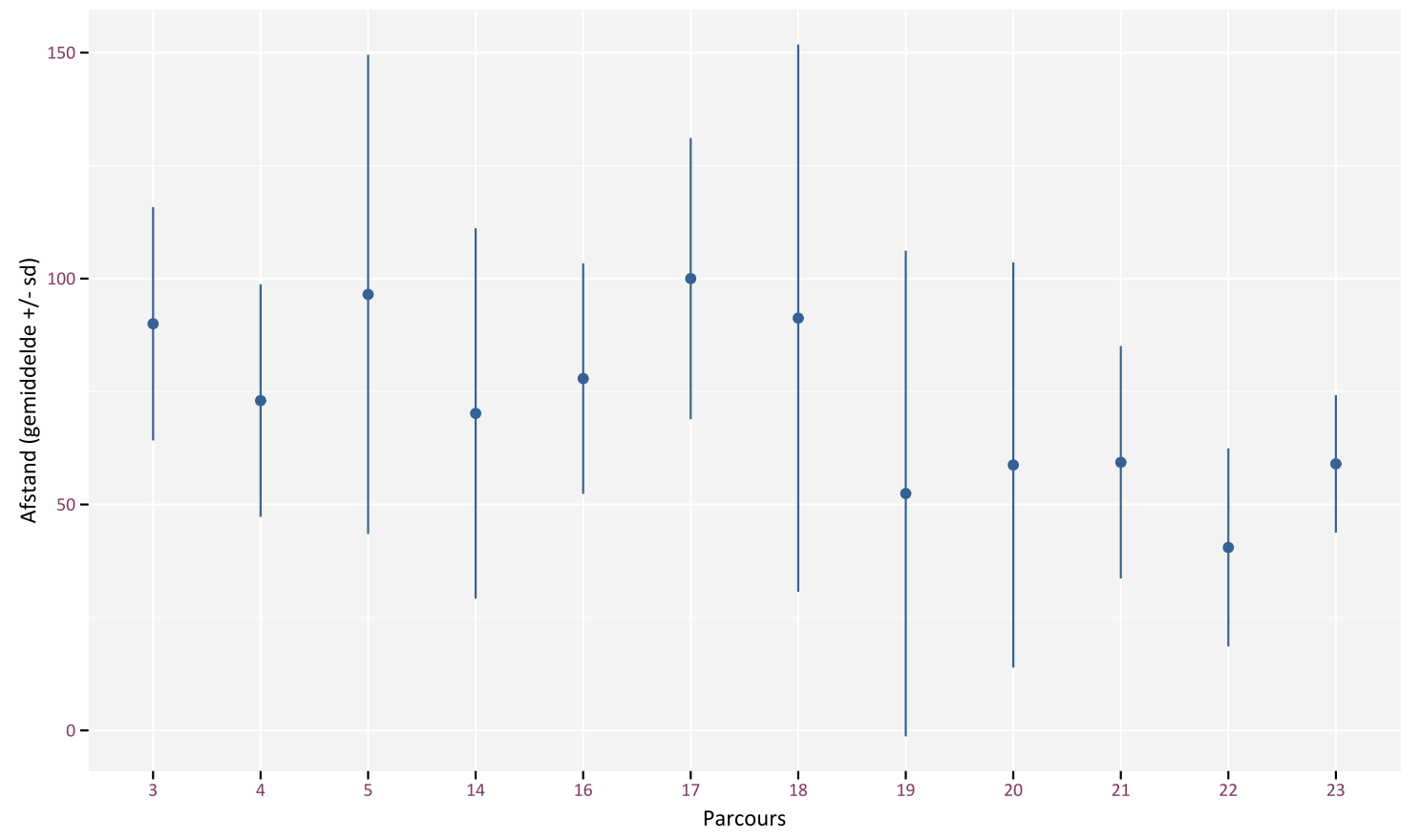

Figuur 4.2: Afstand tussen de waarnemer/teller en een ree/groep reeën, per telparcours in 2021.

\subsubsection{Problemen/knelpunten tijdens het onderzoek}

We beschikten over onvoldoende afstandsmeters om op alle telparcours tegelijk metingen uit te voeren. De metingen gebeurden dus slechts in een deel van het Zoniënwoud. Bovendien volstaat het aantal waarnemingen/waargenomen reeën nog niet om een betrouwbare detectiefunctie te berekenen. Ook zijn de gemeten afstanden de directe afstanden tussen de waarnemer/teller en de ree. Distance sampling vereist echter het gebruik van de loodrechte afstand tussen het telparcours en het dier. Er moet verder onderzocht worden of en hoe het gebruik van de directe in plaats van de loodrechte afstand de densiteitsschatting beïnvloedt.

Figuur 4.3 toont dat de meeste waarnemingen plaatsvonden op een afstand tussen 50 en $100 \mathrm{~m}$. Op basis van het theoretische model zou je echter verwachten dat het maximum aantal waarnemingen vlak bij of op het teltraject gebeuren. De verstoring door de waarnemer of de reactietijd van de waarnemer tussen het ogenblik dat de ree beweegt en het moment dat deze de ree ziet, kunnen verklaren dat er meer reeën 
gezien werden op grotere afstand dan verwacht. Ook het feit dat trajecten op wandelpaden worden uitgevoerd, die door reeën misschien wat worden gemeden, kan een rol spelen. Het softwarepakket Distance corrigeert hiervoor bij de lagere afstandsklassen wanneer het de detectiefunctie inschat.

Door de vele methodologische vragen en problemen werd beslist de berekeningen van de reedensiteit op basis van afstanden niet uit te voeren en de gemeten afstanden enkel te gebruiken om de trend in zichtbaarheid in het boscomplex mee op te volgen.

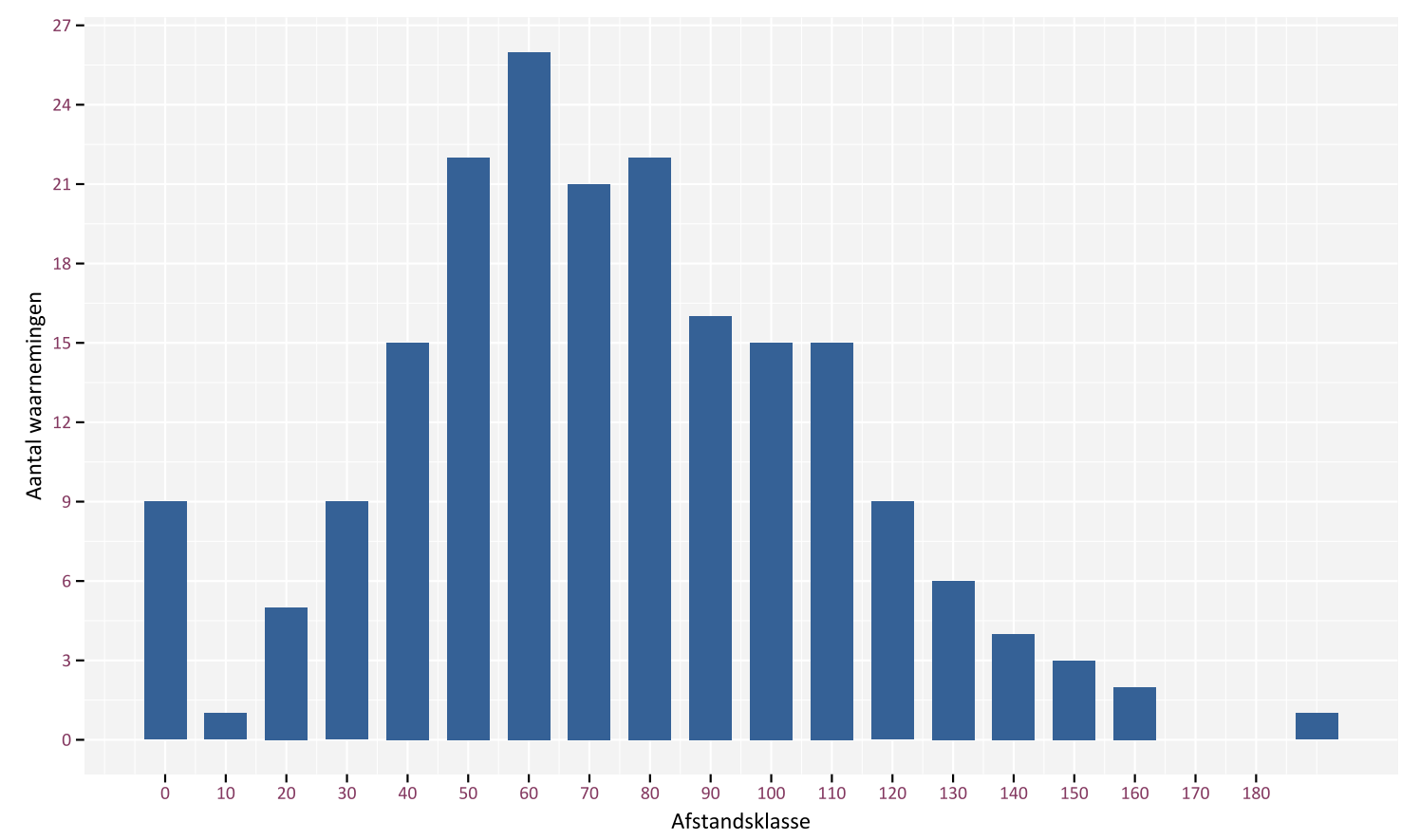

Figuur 4.3: Verdeling van het aantal waarnemingen per waarnemingsafstand, ingedeeld in klassen van 10 $\mathrm{m}$. 


\section{CONCLUSIES}

Na de daling van de gemiddelde kilometerindex die we in 2014, 2015 en 2016 vaststelden, leek de populatie zich te stabiliseren op een lager niveau. Terwijl de gemiddelde KI in de periode 2008-2013 rond 1 ree/km schommelde, oversteeg de index sinds 2014 nooit 0,75. Sinds 2017 zakte de $\mathrm{KI}$ tot onder 0,6. Ook de waarde voor 2021 ligt met een gemiddelde van 0,5 opnieuw aan de lage kant in vergelijking met de cijfers sinds 2014 zodat de afname zich toch verder lijkt te zetten.

In 2016 haalden we al aan dat de dalende cijfers kunnen wijzen op een daling van de reepopulatie in het Zoniënwoud. Om hier uitsluitsel over te kunnen geven, is het nodig om de mogelijke oorzaken van de achteruitgang te identificeren en om de nodige gegevens te verzamelen om die hypotheses te kunnen onderzoeken. Voorbeelden van dergelijke gegevens zijn: aantal aanrijdingen met reeën, informatie over stroperij, impact van loslopende honden, bio-indicatoren van de reepopulatie (bv. aantal embryo's per drachtige geit, het aandeel drachtige geiten), metingen van de recreatiedruk en gegevens over de aanwezigheid van andere wilde hoefdieren. Binnen het kader van de huidige monitoring is het in kaart brengen en opvolgen van deze mogelijke factoren echter niet voorzien.

Om na te gaan of de waargenomen tendens een gevolg kan zijn van een verminderde waarnemingskans, voerden we in 2015 een bevraging uit bij de tellers. Bij hen bestond de perceptie dat de zichtbaarheid in het algemeen verminderd was, wat geheel of gedeeltelijk de daling van de KI zou kunnen verklaren. Een vergelijking van de zichtbaarheidsmetingen uit 2015 en 2018 toont weinig verschillen. De zichtbaarheid is gelijkaardig in beide jaren. Dit was ook te verwachten gezien de korte periode tussen beide metingen en het uitblijven van gebeurtenissen die de zichtbaarheid plots kunnen wijzigen (bv. stormschade, natuurbrand of grootschalige kappingen). Veranderingen in zichtbaarheid in het bos door veranderingen in de vegetatie doen zich, zolang er geen calamiteiten optreden, normaal gezien slechts op langere termijn voor. Ook de meer recente cijfers waarbij afstanden tot waargenomen reeën werden gemeten, wijzen niet op sterke verschillen in zichtbaarheid sinds 2018.

Het verder ontrafelen van de invloed van een mogelijk dalende reepopulatie en vermindering van de zichtbaarheid op de detectiekans stelt uitdagingen aan de interpretatie van de gegevens. Toch is het niet te miskennen dat de cijfers, die systematisch en gestandaardiseerd worden verzameld, sterk afgenomen zijn. Omdat er geen aanwijzingen zijn dat de detectiekans is verminderd, zeker in de periode 2015-2021, lijkt het dus plausibel om uit te gaan van een dalende populatie van reewild in het Zoniënwoud. Een gedetailleerde en geïntegreerde analyse van de waarnemingen, afstanden en zichtbaarheidsmetingen lijkt aangewezen om op zoek te kunnen gaan eventuele ruimtelijke verschillen doorheen het gebied. Deze informatie kan helpen om de oorzaken van de achteruitgang te identificeren zodat maatregelen kunnen worden uitgetest om die te stoppen en indien mogelijk om te keren. 


\section{Referenties}

Boone N., Casaer J., Vercammen J., Malengreaux C. \& Licoppe A. (2020). Ondersteuningsproject bij de uitvoering van de reemonitoring in het Zoniënwoud: Jaarlijks rapport, Periode: 2008-2019. Rapporten van het Instituut voor Natuuren Bosonderzoek, Brussel, België.

Buckland S., Anderson D., KP B., Laake J., Borchers D. \& Thomas L. (2001). Introduction to Distance Sampling, Estimating abundance of biological populations. University Press, Oxford, UK.

Casaer J. \& Malengreaux C. (2008). Studie ter voorbereiding van het monitoren van de reewildpopulatiegrootte in Zoniën Overzicht van bestaande methoden en hun toepasbaarheid in Zoniën. Rapporten van het Instituut voor Natuur- en Bosonderzoek, INBO.R.2008.26, Brussel, België.

Huysentruyt F., Malengreaux C., Vercammen J., Casaer J. \& Licoppe A. (2015). Ondersteuningsproject bij de uitvoering van de reemonitoring in het Zoniënwoud /Mission d'appui pour le recensement du chevreuil dans le massif sonien: Jaarlijks rapport / Rapport annuel, Periode / Période de référence: 2008-2015. Rapporten van het Instituut voor Natuuren Bosonderzoek, Brussel, België.

Malengreaux C. \& Casaer J. (2008). Mission d'appui pour la mise en place d'un recensement chevreuil dans le massif sonien. Mission d'appui financée par l'IBGE et confiée à l'asbl Wildlife and Man : 2008. Wildlife and Man, Brussel, België.

Vercammen J., Huysentruyt F. \& Casaer J. (2011). Reewildtellingen: Overzicht van de resultaten uit de verschillende gebieden. Rapporten van het Instituut voor Natuur-en Bosonderzoek, Brussel, België. 